\title{
ANALISIS NILAI-NILAI PRAGMATIK \\ CERITA RAKYAT SUKU SASAK “TIWOQ-IWOQ”
}

\section{ANALYSIS OF PRAGMATIC VALUES IN THE FOLKTALE OF SASAK \\ TRIBE NAMED “TIWOQ-IWOQ”}

\author{
Pipit Aprilia Susanti \\ STKIP Kie Raha Ternate \\ Pos-el: pipitalovelya@gmail.com \\ Telepon 081239705939
}

\begin{abstract}
Abstrak
Analisis nilai pragmatik cerita rakyat suku sasak "Tiwoq-Iwoq" dilatarbelakangi oleh beberapa faktor yaitu upaya pengenalan sastra rakyat yang semakin berkurang, keberadaan cerita rakyat yang mulai ditinggalkan akibat banyaknya cerita-cerita yang bermunculan dan merosotnya nilai moral di kalangan generasi muda. Tujuannya adalah untuk mengetahui nilai-nilai pragmatik yang ada pada cerita rakyat suku sasak "Tiwoq-Iwoq". Jenis penelitian ini adalah penelitian deskriptif kualitatif. Metode yang digunakan untuk mengumpulkan data dalam penelitian ini adalah studi pustaka, dokumenter, observasi, dan pencatatan. Sedangkan metode analisis data yaitu pragmatik. Berdasarkan hasil dan pembahasan dapat disimpulkan bahwa cerita rakyat suku sasak "TiwoqIwoq" mengandung nilai-nilai pendidikan meliputi moral, sosial, dan religius.
\end{abstract}

Kata Kunci: nilai pragmatik, cerita rakyat

\begin{abstract}
Analysis of pragmatic values in the folktale of Sasak tribe named "Tiwoq-Iwoq" which based on some factors there are, the introduction on local literature which has been decrease lately, the existence of the folktale which started to be left on since there are new stories arise and the sink of moral value in young generations. This research aimed at knowing the pragmatic values in Sasak tribe 'Tiwoq-Iwoq' folktale. This is a descriptive qualitative research and used library research, documenter, observation, and notes as method of gathering the data. To analyze the research, the researcher uses pragmatic analysis. Based on the analysis it can be concluded that the Sasak Tribe 'Tiwoq Iwoq' folktale contains education values such as moral, social, and religious.
\end{abstract}

Keywords: Pragmatic values, folktale

\section{A. Pendahuluan}

Tren Globalisasi yang mulai memasuki bangsa ini sudah mulai kita rasakan. Pengaruh bangsa asing tidak hanya merambah di dunia fashion, musik, film layar lebar, buku-buku bacaan tetapi juga mulai menghantam nilai-nilai luhur budaya bangsa ini. Sekarang ini sulit sekali kita temui generasi muda yang peduli terhadap nilai-nilai budaya bangsa. Generasi muda lebih fokus pada kemajuan teknologi yang saat ini sedang digemari seperti facebook, twitter, path, instagram, whatsup, dan line. Kemajuan teknologi tidak semuanya berdampak negatif tetapi jika pemakaiannya berlebihan dan membuat pengguna kemajuan teknologi lupa akan jati diri sesungguhnya maka akan fatal akibatnya.

Nilai-nilai luhur budaya sangat erat kaitannya dengan karya sastra tradisi lisan 
salah satu contohnya adalah cerita rakyat. Seiring dengan perkembangan zaman, generasi muda tidak harus mencari cerita rakyat ke pelosok-pelosok desa, tetapi dengan kemajuan teknologi generasi muda bisa menemukan cerita rakyat nusantara dalam bentuk e-book. Meski sudah mengikuti perkembangan zaman, namun hasilnya tetap sama. Generasi muda tetap kurang tertarik pada cerita rakyat yang sudah dikemas semoderen mungkin. Kondisi inilah yang membuat nilai-nilai luhur budaya semakin merosot tajam keberadaannya.

Membahas karya sastra memang tidak akan ada habisnya, apalagi secara sadar kita mengetahui bahwa karya sastra lahir tidak dari sebuah kekosongan. Sastra lahir dan berkembang di tengah-tengah masyarakat sehingga sastra merupakan bagian dari kebudayaan masyarakat. Karya sastra lahir sebagai hasil dari proses karya budaya yang panjang dan berisi banyak pengalaman. Adanya imajinasi pada sebuah karya sastra akan menyebabkan karya tersebut menjadi karya imajinatif yang di dalamnya berisi pikiran, perasaan, ide, dan harapan yang terangkum menjadi satu dan dikemas dengan menggunakan bahasa yang indah sehingga menjadi sebuah karya sastra.

Sastra di Indonesia mengalami perkembangan hingga sekarang ini. Berawal dari sastra yang dikenal dengan sastra lama atau sastra melayu dimana karya sastra saat itu tercipta dan berkembang sebelum masuknya unsur-unsur modernisme ke dalam sastra tersebut. Dikatakan sebagai sastra melayu karena bahasa melayu merupakan media pengantar yang paling dominan. Dalam sastra melayu dikenal bentuk sastra yang disebut dengan sastra rakyat yaitu sastra yang disampaikan secara turun-temurun, sesuatu yang telah mentradisi. Salah satu bentuk sastra rakyat yang masih dikenal hingga sekarang adalah legenda/cerita rakyat. Legenda disebut juga cerita tentang asal usul terbagi menjadi tiga jenis yaitu pertama cerita asal usul dunia tumbuh-tumbuhan, kedua cerita asal-usul dunia binatang, dan ketiga cerita asal-usul terjadinya suatu tempat (Kosasih,2009: 346).
Zaman dahulu perkembangan sastra rakyat dikenal oleh masyarakat dari mulut ke mulut. Hal tersebut tidak bertahan lama, saat ini sastra rakyat tidak banyak dikenal orang, baik sastra lisan maupun sastra tulisan. Pada kalangan generasi muda dapat dikatakan sastra rakyat mulai ditinggalkan karena dianggap tidak menarik. Oleh karena itu, perlu dilakukan usaha untuk menggali, mengembangkan, memperkenalkan sastra rakyat yang ada pada suatu daerah tersebut karena hal tersebut merupakan salah satu kekayaan bangsa yang didalamnya terkandung nilai-nilai yang mencerminkan kepribadian bangsa. Hal serupa juga disebutkan oleh Sutrisno dalam Alaini (2005:1) bahwa penggalian karya sastra daerah yang tersimpan dan tersebar di daerah-daerah akan menghasilkan ciri-ciri khas kebudayaan daerah yang meliputi pula pandangan hidup serta landasan falsafah yang mulia dan bernilai tinggi.

Nusa Tenggara Barat sebagai salah satu provinsi di Indonesia tidak hanya memiliki kekayaan alam tetapi juga budayanya. Satu diantara kekayaan budaya yang dimiliki pulau Lombok adalah sastra lisan yaitu cerita rakyat. Cerita rakyat disebarkan dari mulut ke mulut, diturunkan secara turun temurun. Peran cerita rakyat pada saat itu digunakan sebagai alat didik anakanak bagi orang tua. Cerita rakyat yang ada menggambarkan ajaran-ajaran dalam kehidupan sehari-hari seperti nilai ketabahan, perilaku terhadap orang tua, keperwiraan, nilai agama (ketaqwaan), dan ajaran agar supaya kita tidak berprilaku tidak cermat.

Seiring dengan perkembangan zaman, keberadaan cerita rakyat yang banyak mengandung falsafah hidup mulai ditinggalkan. Ketertarikan generasi muda terhadap sastra modern mengakibatkan sastra rakyat hanya sebatas sejarah. Akibatnya kemerosotan moral terjadi di mana-mana, tidak hanya di kota besar tetapi juga di daerah terpencil. Realita ini sebagai dampak dari tidak ditanamkannya nilai-nilai yang penting dalam kehidupan sehari-hari sejak awal.

Berdasarkan uraian tersebut, maka penelitian yang berjudul "Analisis Unsur 
Intrinsik dan Pragmatik Cerita Rakyat Suku Sasak "Tiwoq-Iwoq" penting dilakukan. Cerita rakyat ini berkembang di daerah Lombok Tengah, digunakan oleh orang tua sebagai media pendidikan untuk anakanaknya. Namun, keberadaannya mengalami pergeseran dikarenakan banyak bermunculan cerita-cerita baru. Kecintaan terhadap karya sastra daerah mulai terkikis. Melihat keadaan tersebut, penelitian terhadap cerita rakyat "Tiwoq-Iwoq" ini diharapkan dapat memberikan masukan betapa pentingnya dikenalkannya cerita rakyat daerah kepada generasi muda.

\section{Kajian Teori \\ Kajian Pragmatik}

Pragmatik merupakan kajian yang bersifat praktis dan berguna bagi umum, bersifat mengutamakan segi kepraktisan dan kegunaan (kemanfaatan), dan bersangkutan dengan nilai-nilai praktis (KBBI, 2007:891). Selain itu Wiyatmi (2008:85) juga mendefinisikan pragmatik adalah pendekatan yang memandang karya sastra sebagai sarana untuk menyampaikan tujuan tertentu kepada pembaca.

Berdasarkan pendapat di atas, dapat disimpulkan bahwa yang dimaksud pragmatik dalam penelitian ini adalah salah satu jenis kajian karya sastra yang berprinsip bahwa karya sastra yang baik dapat memberikan manfaat dan nilai-nilai praktis, misalnya nilai pendidikan yang mencakup moral, religius, dan sosial kepada pembacanya.

Dalam karya sastra, nilai pendidikan itu terlihat dari pesan-pesan yang ingin disampaikan oleh pengarang kepada pembaca yang berupa nilai baik ataupun buruk dalam sebuah karya sastra. Hal inilah yang menjadi tanggung jawab pembaca untuk memilah dan memilih mana hal-hal yang harus diambil dan yang harus ditinggalkan. Pendidikan senantiasa menanamkan norma-norma susila kepada anak-anak, agar anak memiliki nilainilai dan norma-norma itu di dalam dirinya dan selanjutnya dapat berbuat dan bersikap sesuai dengan nilai-nilai dan norma-norma yang telah dimiliki.

Jadi, nilai pendidikan diartikan sebagai suatu yang diyakini oleh manusia yang baik dan berharga untuk mengubah sikap dan perilaku dalam rangka meningkatkan pengetahuannya agar menjadi anggota masyarakat yang berguna bagi manusia, bangsa, dan negara. Pengertian nilai pendidikan yang dikemukakan ternyata mencakup hal yang cukup luas dan tentunya akan berkaitan dengan nilai-nilai lain dalam kehidupan manusia. Hal serupa juga dikatakan oleh Noor Syam dalam Hilmiah (2010:14) yang membagi jenis nilai pendidikan meliputi: (a) nilai-nilai moral, (b) nilai-nilai ilmiah, (c) nilai-nilai sosial, dan (d) nilai-nilai religius. Diantara nilai-nilai tersebut, penelitian kali ini akan memfokuskan pada nilai-nilai moral, sosial, dan religius.

\section{Nilai Moral}

Moral dalam karya sastra biasanya mencerminkan pandangan hidup pengarang yang bersangkutan, pandangan tentang nilainilai kebenaran, dan hal itulah yang disampaikan kepada pembacanya. Menurut Kenny dalam Nurgiyantoro (2010:321) nilai moral dalam cerita dimaksudkan sebagai suatu saran yang berhubungan dengan ajaran moral yang bersifat praktis, yang dapat diambil dan ditafsirkan lewat cerita yang bersangkutan oleh pembaca. Chulsum dan No (dalam Hilmiah, 2010:16) menyatakan nilai moral adalah ajaran tentang baik buruk mengenai akhlak, budi pekerti, ajaran, etika atau sopan santun, kebaikan terhadap sesama, berani dan sebagainya.

Diharapkan dengan ajaran moral yang terkandung dalam karya sastra dapat memberikan sesuatu yang bermanfaat untuk pembacanya. Ia merupakan petunjuk yang sengaja diberikan oleh pengarang tentang berbagai hal yang berhubungan dengan masalah kehidupan. Kehadiran nilai moral dalam cerita fiksi dipandang sebagai saran terhadap perilaku moral yang bersifat praktis karena ajaran moral yang disampaikan lewat sikap dan perilaku konkret sebagaimana yang ditampilkan oleh para tokoh cerita. 


\section{Nilai Sosial}

Manusia adalah makhluk sosial. Sebagai makhluk sosial, manusia tidak dapat hidup sendiri sehingga memerlukan orang lain dalam berinterkasi. Interaksi sosial seperti inilah diperlukan nilai-nilai yang merupakan intern dengan antar hubungan sosial, nilainilai sosial ini berkaitan dengan adanya rasa saling memahami, saling simpati, saling menghargai, saling menghormati, dan saling mencintai, bahkan juga sikap atau watak manusiawi yang antipati, salah paham, dan saling membenci. Dengan demikian dapat dikatakan bahwa tiada hubungan sosial tanpa nilai-nilai atau norma, dan tiada nilai-nilai tanpa hubungan sosial.

Mengingat manusia diciptakan Tuhan sebagai makhluk sosial, maka manusia tidak bisa lepas dari sesamanya. Lebih-lebih bila seseorang belum mampu memenuhi kebutuhannya sendiri. Oleh karena itu, individu secara bersama membentuk lingkungan bermasyarakat yang selaras dan seimbang agar dapat menjami kehidupan yang lebih baik.

Berdasarkan uraian di atas, maka dapat disimpulkan bahwa nilai sosial adalah salah satu pendidikan yang berkaitan erat dengan kehidupan bermasyarakat dan usaha menjaga keseimbangan hidup dalam bermasyarakat. Hal ini dapat terwujud jika didalamnya terdapat kasih sayang, tolong-menolong, kesetiaan, balas budi, dan mementingkan kepentingan bersama.

\section{Nilai Religius}

Nilai religius ini merupakan salah satu nilai yang terpenting dalam kehidupan. Sebagai makhluk ciptaannya, nilai ini sangat diperlukan untuk selalu mengingatkan kita kepada sang pencipta.

Nilai religius adalah segala sesuatu yang berhubungan dengan tuhan atau kepercayaan kepada tuhan yang Mahaesa. Penanaman nilai ini dapat dilakukan sedini mungkin dengan membiasakan diri untuk taat dan patuh dalam menjalankan perintah serta menjauhi segala larangan-Nya. Adapun wujud dari nilai religius dapat berupa berdoa atau memohon kepada tuhan, ungkapan rasa syukur dan sikap kepasrahan.

Religiusitas adalah perasaan dan pengalaman bathin atau sikap mental dalam hubungan manusia dengan Tuhan yang dihayati dan dimaknai secara mendalam. Religiusitas dalam konteks ini meliputi beberapa aspek fundamental antara lain yaitu: a. Aqidah

Menurut Zakiah Darajat dalam Hindrayanti (2009:3), Aqidah secara bahasa berarti ikatan, secara terminologi berarti landasan yang mengikat, yaitu keimanan, itu sebabnya ilmu tauhid disebut juga ilmu aqaid (jama' aqidah) yang berarti ilmu mengikat. Ajaran islam sebagaimana dicantumkan dalam alquran dan sunnah adalah merupakan ketentuan-ketentuan dan pedoman keimanan. Jadi, aqidah (keimanan) adalah suatu sikap jiwa yang diperoleh karena pengetahuan yang berproses sedemikian rupa sehingga membentuk tata nilai (norma) maupun pola prilaku seseorang.

Dari pendapat-pendapat $\mathrm{di}$ atas, disimpulkan bahwa aqidah adalah keyakinan kepada Allah dan hal ihwal yang berhubungan dengan Allah. Atau dengan kata lain aqidah adalah keyakinan dasar yang menguatkan/meneguhkan jiwa sehingga jiwa terbebas dari rasa kebimbangan atau keraguan yang disebut iman (dalam ajaran islam).

Hal-hal yang fundamental yang terkait dengan skripsi ini dalam aqidah adalah sebagai berikut:

\section{(1). Tauhid}

Kata tauhid berasal dari kata bahasa Arab "Wahhada Yuwahhidu Tauhidan" dari kata dasar inilah lahir istilah "tauhid". Tauhid adalah suatu kepercayaan atau keimanan kepada Tuhan Yang Mahaesa. Jadi, ketauhidan adalah suatu kepercayaan atau keimanan yang menegaskan bahwa hanya Tuhanlah yang menciptakan, member hukuman, dan mengatur alam semesta. Hal ini dirangkum dalam kalimat Tauhid Laa ila haillAllah.

Untuk lebih jelasnya, ayat dalam Q.S Al-Baqarah (165) menjelaskan bahwa tauhid disimpulkan sebagai pemurnian kecintaan 
kepada Allah yang diiringi dengan rasa rendah hati dan penghambaan hanya kepada-Nya. Inilah hakikat agama islam, karena islam maknanya ialah menyerahkan diri kepada Allah semata-mata disertai dengan kepatuhan mutlak kepada-Nya dengan penuh rasa rendah diri dan cinta. Kepercayaan terhadap adanya alam gaib. Kepercayaan terhadap adanya alam gaib artinya setiap manusia yang beriman harus mempercayai adanya alam lain di balik alam semesta ini; seperti adanya alam para malaikat, jin, dan roh manusia yang terlepas dari jasadnya yang biasa disebut alam baka, dimana dalam alam tersebut manusia terlepas dari segala urusan yang bersifat duniawi, termasuk adanya surga dan neraka.

\section{(2). Iman terhadap takdir}

Menurut Nurdin dalam Hindrayanti (2009:16) mengatakan bahwa iman terhadap takdir Allah (qada' dan qadar) adalah ketentuan Allah bagi manusia yang menunjukkan kemahakuasaan Allah dalam menentukan nasib manusia. Allah mahakuasa dan mahatahu tentang nasib seluruh makhluknya, tapi tak seorang pun makhluk yang mengetahui nasibnya. Allah Mahakuasa dan Maha berkehendak, oleh karena itu, jika Allah menghendaki maka Allah Mahakuasa untuk merubah nasib makhluk-Nya, jika makhluk-Nya berusaha untuk mengubahnya.

Berdasarkan definisi di atas dapat dikemukakan bahwa Allah telah menetapkan ketentuan-ketentuan dan nasib manusia di alam Azali yang disebut qada, Demikian pula Allah berkehendak untuk melaksanakan ketentuan-ketentuan-Nya yang disebut qadar.

Manusia dituntut untuk berusaha terusmenerus mengubah nasibnya dengan penuh keyakinan bahwa Allah akan memberikan yang terbaik bagi dirinya. Allah Mahaadil untuk memberikan nilai pada setiap usaha yang dilakukan manusia, termasuk mengubah nasib dirinya. Setelah segala upaya dilakukan dan kemudian berhasil, itu adalah takdir. Demikian pula setelah usha dilakukan secara maksimal, kemudian gagal, itupun takdir. Setiap takdir Allah adalah yang terbaik bagi manusia. Tetapi yang terbaik menurut Allah, tidak selalu baik menurut keinginan manusia.
Karena itu, untuk mencapai takdir yang baik, manusia dituntut untuk berusaha maksimal dan kemudian berdoa kepada Allah secara khusyuk, sehingga apapun yang diterimanya bermakna baik dihadapan Allah.

Selain itu, ada juga pendapat lain tentang iman terhadap takdir yaitu meyakini bahwa sesuatu yang telah ditakdirkan mengenai diri kita sendiri adalah ketetapan dari Tuhan dan menjadi motivasi untuk meraih kehidupan yang lebih baik serta menerima segala cobaan dengan sabar dan bijaksana.

\section{b. Syariah}

Menurut Zakiah Darajat dalam Hindrayanti (2009:17), syariah adalah ketentuan-ketentuan agama yang merupakan pegangan bagi manusia di dalam hidupnya untuk meningkatkan kualitas hidupnya dalam rangka mencapai kebahagiaan dunia dan akhirat. Syariah sebagai ketentuan Allah swt yang implisit atau eksplisit, baik yang terdapat dalam alquran maupun yang terdapat dalam alam semesta beserta tanda-tandanya. Syariah mencakup seluruh aspej kehidupan manusia sebagai individu, warga masyarakat, dan sebagai subyek alam semesta. Syariah berarti aturan atau undang-undang yang diturunkan Allah, adapun bagia dari syariah, yaitu:

(1). Hubungan manusia dengan Tuhannya Manusia sebagai makhluk ciptaan, pasti memiliki hubungan erat dengan penciptannya. Hubungan itu berupa ketaatan, ketundukan, dan kepatuhan kepada Allah dibuktikan dalam bentuk pelaksanaan ibadah yang tata caranya diatur sedemikian rupa oleh syariat Islam.

(2). Hubungan sesama manusia

Islam mengakui manusia sebagai makhluk sosial. Kehidupan manusia di muka bumi ini tidak terlepas dari manusia lainnya. Dalam hubungan sesama manusia, kedua belah pihak saling memberikan perhatian dan kepedulian antara manusia yang satu dengan manusia yang lainnya yang dilandasi oleh kasih sayang. 
(3). Hubungan manusia dengan alam semesta

Dalam hubungan dengan alam, syariat islam meliputi aturan dalam mewujudkan hubungan yang harmonis antara manusia dengan alam dan mendorong untuk saling memberi manfaat.

\section{c. Akhlak}

Menurut Nurdin dalam Hindrayanti (2009:19) kata akhlak berasal dari kata khalaqa, jamak dari khuluqan (bahasa Arab) yang berarti perangai, tabiat, dan adab; atau dari kata khalqun (bahasa Arab) yang berarti kejadian, buatan atau ciptaan. Jadi, secara etimologis akhlak berarti perangai, adab, tabiat atau system prilaku yang dibuat.

Secara istilah, akhlak adalah system nilai yang mengatur pola sikap dan tindakan manusia di dunia. System nilai yang dimaksud adalah ajaran Islam, dengan alquran dan sunnah rasul sebagai sumber nilainya serta ijtihad (hukum islam) sebagai metode berpikir islam.

Dari pendapat di atas, dapat disimpulkan akhlak adalah tingkah laku, budi pekerti yang melekat pada jiwa seseorang untuk melakukan suatu hal atau perbuatan.

(1). Akhlak kepada Allah meliputi:

a). Beribadah kepada Allah, yaitu melaksanakan perintah Allah untuk menyembah-Nya sesuai dengan perintah-Nya.

b). Berdzikir kepada Allah, yaitu mengingat Allah dalam berbagai situasi dan kondisi, baik diucapkan dengan mulut maupun dalam hati.

c). Berdoa kepada Allah, yaitu memohon apa saja kepada Allah. Doa merupakan inti ibadah karena ia merupakan pengakuan akan keterbatasan dan ketidakmampuan manusia sekaligus pengakuan akan Mahakuasa Allah terhadap segala sesuatu.

d). Tawakkal kepada Allah yaitu berserah diri sepenuhnya kepada Allah dan menunggu hasil pekerjaan atau menanti akibat dari suatu keadaan

e). Tawadhu kepada Allah yaitu rendah hati di hadapan Allah. Mengakui bahwa dirinya rendah dan hina dihadapan Allah Yang Mahakuasa.

(2). Akhlak kepada orang tua

Pengabdian kepada orang tua adalah salah satu perilaku yang tergolong akhlak mulia. Dengan berbakti dan memuliakan serta menghormati ibu bapak adalah kewajiban semua anak. Akhlak kepada orang tua dapat diwujudkan dengan perbuatan antara lain: menyayangi dan mencintai kedua orang tua, bertutur kata sopan dan lemah lembut, menaati perintahnya, meringankan beban, serta menyantuni mereka jika sudah tua dan tidak mampu lagi berusaha.

(3). Akhlak kepada Takdir Allah

Berakhlak kepada takdir Allah yaitu manusia harus menerima apa yang menajdi keputusan Allah dan meyakini bahwa keputusan Allah itu justru yang terbaik baginya.

Untuk mencapai ketaatan dan kepatuhan tersebut, manusia harus terus menerus menyadari dirinya dan kedudukannya sebagai makhluk Allah kepada dirinya. Dimana dijelaskan antara lain sebagai berikut.

a). Sabar adalah sikap jiwa yang ditampilkan dalam penerimaan terhadap sesuatu, baik berkenaan dengan penerimaan tugas dalam bentuk suruhan dan larangan maupun bentuk penerimaan terhadap perlakuan orang lain serta sikap menghadapi suatu musibah.

b). Syukur adalah sikap prilaku yang menunjukkan penerimaan terhadap suatu pemberian atau anugerah dalam bentuk pemanfaatan dan penggunaan yang sesuai dengan kehendak pemberinya.

Dari uraian di atas, disimpulkan bahwa antara aqidah, syariah dan akhlak masing-masing saling berkaitan. Aqidah atau iman merupakan keyakinan yang mendorong seorang untuk melaksanakan syariah. Apabila syariah telah dilaksanakan berdasarkan aqidah akan lahir 
akhlak. Oleh karena itu, iman tidak hanya dalam hati tetapi ditampilkan dalam bentuk perbuatan.

\section{Metode Penelitian}

Arikunto (1999: 236) menyebutkan metode dan teknik pengumpulan data yang digunakan dalam penelitian ini adalah

1. Studi Pustaka, diterapkan untuk mempelajari sasaran dan kepustakaan yang berkaitan dengan permasalahan yang dipecahkan dalam skripsi ini untuk menemukan pustaka yang efektif. Kepustakaan yang dimaksud adalah buku-buku teori sastra dan metodologi penelitian.

2. Dokumenter, bahan-bahan penting yang dipergunakan untuk mengidentifikasi data-data tertulis tentang nilai-nilai yang terkandung didalamnya kemudian mendeskripsikan sasaran sebagai penunjang pemahaman cerita rakyat.

3. Observasi yaitu mengamati sasaran cermat untuk menemukan, memperoleh, mendapatkan, dan menetapkan data yang berupa nilai pendidikan, moral, sosial dan agama sebagai bahan acuan dalam memahami cerita rakyat "Tiwoq-Iwoq", pustaka dan dokumen dalam rangka menemukan acuan dan data yang efektif guna memecahkan masalah.

\section{Metode Analisis Data}

Analisis data adalah proses mencari dan menyusun secara sistematis data-data yang diperoleh dan hasil wawancara, catatan lapangan, dan dokumnetasi dengan cara mengorganisasikan data ke dalam kategori, menjabarkan ke dalam unit-unit, melakukan sintesis, menyusun ke dalam pola, memilih mana yang penting dan yang akan dipelajari dan membuat simpulan sehingga mudah dipahami oleh diri sendiri maupun orang lain (Sugiyono, 2011:244).

Proses analisis data dalam penelitian ini dilakukan dalam satu proses. Proses berarti penganalisisan data telah mulai dilakukan sejak pengumpulan data dan dikerjakan secara intensif sampai berakhirnya penelitian. Adapun prosedur analisis data pada penelitian ini adalah dengan menggunakan langkahlangkah sebagai berikut:

Langkah 1: Membaca cerita rakyat "Tiwoq-Iwoq" untuk memahami struktur global cerita rakyat tersebut secara berulang-ulang dan cermat kata demi kata dan kalimat demi kalimat.

Langkah 2: Mengambil data yang berkaitan dengan nilai pendidikan yang meliputi nilai moral, religius, dan sosial dalam cerita rakyat "TiwoqIwoq" tersebut.

Langkah 3: Menganalisis nilai pendidikan yang meliputi nilai moral, religius, dan sosial melalui perilaku tokoh dan kalimatkalimat.

Langkah 4: Menyimpulkan hasil yang disadarkan pada analisis data secara keseluruhan.

\section{Pembahasan}

\section{Analisis Pragmatik}

Pragmatik adalah pendekatan yang memandang karya sastra sebagai sarana untuk menyampaikan tujuan tertentu kepada pembaca. Dalam hal ini tujuan tersebut dapat berupa tujuan politik, pendidikan, moral, agama maupun tujuan yang lain. Dalam praktiknya, pendekatan ini mengkaji dan memahami karya sastra berdasarkan fungsinya untuk memberikan pendidikan (ajaran) moral, agama, maupun fungsi sosial lainnya. Semakin banyak nilai pendidikan moral atau agama yang terdapat dalam karya sastra dan berguna bagi pembacanya, makin tinggi nilai karya sastra tersebut.

Wujud nilai dapat dilihat dari tindakan yang dilakukan oleh para tokoh. Setelah mengetahui tentang wujud nilai maka pembaca dapat mengambil hikmah, pesan atau amanat yang ada dalam cerita rakyat tersebut. Sikap dan tingkah laku tokoh yang terpuji ataupun yang kurang terpuji, baik mereka berlaku sebagai tokoh antagonis maupun tokoh protagonist, akan selalu ditiru oleh pembaca. Untuk itulah pembaca diharapkan 
dapat mengambil pesan atau hikmah sendiri atau orang lain yang lebih mengetahui dengan benar cerita rakyat "Tiwoq-Iwoq" tersebut.

\section{Nilai Moral}

Nilai moral adalah suatu bagian dari nilai, yaitu nilai yang menangani kelakuan baik atau buruk dari manusia. Nilai moral berhubungan dengan kelakuan atau tindakan manusia. nilai moral inilah yang lebih terkait dengan tingkah laku kehidupan kita seharihari.

Cerita rakyat "Tiwoq-Iwoq" terdapat nilai-nilai moral yang dapat ditiru oleh pembaca. Nilai-nilai moral tersebut dapat terlihat dari sikap dan sifat tokoh dalam cerita rakyat tersebut. Nilai pendidikan moral dari cerita rakyat "Tiwoq-Iwoq" antara lain :

a. Menyayangi dan bertanggung jawab terhadap orang tua.

Sikap menyayangi dan bertanggung jawab terhadap adalah salah satu sikap yang patut ditiru.

b. Saling Menasihati dalam Keluarga

Sikap ini sangat perlu dimiliki dalam sebuah keluarga. Saling menasihati dapat menghindari kekacauan. Dalam cerita rakyat ini, kita diajarkan untuk lebih terbuka kepada anggota keluarga yang ada, dengan begitu masalah yang kita hadapi dapat diselesaikan secara bersamasama. Nasihat dari orang tua merupakan kekuatan yang terbesar bagi anakanaknya.

c. Menaati Nasihat Orang Tua

Sikap Taat kepada orang tua di zaman sekarang ini semakin sulit ditemukan. Dalam cerita rakyat ini, banyak kita temukan peristiwa, tokoh utama selalu menaati nasihat orang tua satu-satunya yang masih ada yaitu nenek.

d. Menepati janji

Janji adalah hutang. Jika kita berjanji maka kita wajib melakukannya. Jika tidak maka kita akan disebut dengan munafik. Dalam cerita rakyat ini, "Tiwoq-Iwoq" menepati janji dengan ibu Naga. Ini terlihat dalam kutipan berikut.

e. Sabar
Sabar adalah mampu menahan diri. Sebagai makhluk sosial, kita disarankan untuk memiliki sikap sabar. Dengan bersabar, manusia dapat menghindari perpecahan dan pertikaian.

\section{Nilai Sosial}

Nilai sosial adalah salah satu dari nilai pendidikan yang terkandung dalam karya sastra. Sesuai dengan fungsinya karya sastra tidak hanya indah tetapi juga bermanfaat. Dalam cerita rakyat ini banyak terlihat interaksi sosial yang terjadi. Tokoh-tokoh dalam cerita rakyat ini senantiasa melakukan sikap dan prilaku sosial yakni peduli sesama, tidak melakukan kekerasan, hidup untuk memberi bantuan tanpa mengharap imbalan, dan memaafkan kesalahan orang lain.

a. Peduli Sesama

Sikap peduli sesama dalam cerita rakyat ini terlihat dari sikap "Tiwoq-Iwoq" yang mau menerima sahabat-sahabat barunya serta mengajak mereka melakukan perjalanan.

b. Tidak Melakukan Kekerasan

Sebagai makhluk sosial sepantasnya saling menyayangi dan mengasihi. Dalam kehidupan bermasyarakat seringkali kita temukan seseorang yang melakukan kesalahan tidaklah pantas bagi kita membalas kesalahan tersebut dengan tindakan kekerasan.

c. Ikhlas

Ikhlas adalah menerima sesuatu dengan lapang dada atau melakukan sesuatu tanpa mengharapkan imbalan.

d. Memaafkan Kesalahan Orang lain Maaf adalah pembebasan orang lain dari hukuman karena kesalahan. Dalam kehidupan bermasyarakat, diperlukan sikap memaafkan kesalahan orang lain dan sikap meminta maaf kepada orang lain. Dengan demikian, perpecahan tidak akan terjadi.

\section{Nilai Religius}

Nilai Religius adalah segala sesuatu yang berhubungan dengan Tuhan atau kepercayaan kepada Tuhan. Semua makhluk hidup di dunia ini merupakan ciptaan Tuhan. 
Sebab itulah, antara makhluk dan Tuhan terdapat hubungan yang erat, yaitu Tuhan sebagai pencipta dan makhluk adalah yang diciptakannya. Dalam cerita rakyat ini ada beberapa kejadian yang sarat dengan nilai religius. Berdasarkan pendapat yang dikemukakan Zakiah Darajat bahwa nilai religius meliputi beberapa aspek fundamental yaitu aqidah, syariah dan akhlak. Ketiga aspek tersebut dapat kita petik dalam cerita rakyat ini antara lain.

a. Aqidah

Aqidah adalah keyakinan kepada Allah swt dan hal ihwal yang berhubungan dengan Allah swt. atau dengan kata lain aqidah adalah keyakinan dasar yang menguatkan/meneguhkan jiwa sehingga jiwa terbebas dari rasa kebimbangan atau keraguan yang disebut iman (dalam ajaran Islam)

\section{(1). Tauhid}

Tauhid adalah suatu kepercayaan atau keimanan kepada Tuhan Yang Mahaesa. Dalam cerita rakyat ini terkandung nilai ketauhidan.

(2). Kepercayaan terhadap Alam Gaib Kepercayaan terhadap adanya alam gaib artinya setiap manusia yang beriman harus mempercayai adanya alam lain di balik alam semesta ini; seperti adanya alam para malaikat, jin, dan roh manusia yang telah terlepas dari jasadnnya yang biasa disebut alam baka, dimana dalam alam tersebut manusia terlepas dari segala urusan yang bersifat dunaiwi, termasuk adanya surga dan neraka. Dalam cerita rakyat ini juga mengandung nilai-nilai yang berkaitan dengan kepercayaan terhadap alam gaib.

(3). Iman terhadap Takdir

Iman terhadap takdir Allah adalah ketentuan Allah bagi manusia yang menunjukkan ke-Maha Kuasaan Allah dalam menentukan nasib manusia. manusia dituntut untuk berusaha terus menerus mengubah nasibnya dengan penuh keyakinan bahwa Allah akan memberikan yang terbaik bagi dirinya. Cerita rakyat ini mengandung nilai religius khususnya iman terhadap takdir.

b. Akhlak

Secara istilah, akhlak adalah sistem nilai yang mengatur pola sikap dan tindakan manusia di atas bumi. Akhlak juga dapat didefinisikan sebagai tingkah laku, budi pekerti yang melekat pada jiwa seseorang untuk melakukan suatu hal atau perbuatan. Perbuatan yang dimaksud dari definisi akhlak di atas adalah sebagai berikut

1. Akhlak kepada Allah meliputi beribadah kepada Allah, berdoa kepada Allah, Tawakkal kepada Allah. Berikut akan dipaparkan secara terperinci.

(a). Beribadah kepada Allah yaitu melaksanakan perintah Allah untuk menyembah-Nya sesuai dengan perintah-Nya.

(b). Berdoa kepada Allah yaitu memohon apa saja kepada Allah. Sebagai ciptaan-Nya seringkali kita berdoa kepada Tuhan memohon kesehatan dan perlindungan.

(c). Tawakkal kepada Allah yaitu berserah diri sepenuhnya kepada Allah dan menunggu hasil pekerjaan atau menanti akibat dari suatu keadaan.

2. Akhlak Kepada Kedua Orang Tua adalah berbuat baik kepada keduanya dengan ucapan dan perbuatan. Berbuat baik kepada orang tua dibuktikan dalam bentuk perbuatan antara lain: Menyayangi dan mencintai kedua orang tua, menaati perintah, meringankan beban, serta menyantuni mereka jika sudah tua dan tidak mampu lagi berusaha. Cerita rakyat ini mengajarkan akhlak pada orang tua yang disebutkan di atas. Berikut penjelasannya.

(a). Menyayangi dan Mencintai Orang Tua adalah sikap yang harus dimiliki setiap anak kepada orang tua. Sikap seperti ini adalah salah satu tanda bakti kita kepada mereka yang sudah memberikan kasih sayang mereka kepada kita dari kecil hingga kita dewasa. 
(b). Menaati perintah adalah salah satu kewajiban yang harus dilakukan setiap anak kepada orang tuanya.

(c). Meringankan Beban adalah kewajiban seorang anak, apalagi jika orang tua sudah tua. Tidak pantas orang tua yang sudah tua masih dibebankan untuk mencari nafkah untuk memenuhi kebutuhan.

(d). Menyantuni Orang Tua. Ketika kita masih kecil, segala kebutuhan selalu dipenuhi oleh orang tua kita. Demikian pula ketika mereka sudah tua renta tidak bisa melakukan pekerjaan apapun, tugas untuk memenuhi kebutuhan adalah tanggung jawab seorang anak.

3. Akhlak Kepada Takdir Allah adalah manusia harus menerima apa yang menjadi keputusan Allah dan manusia meyakini bahwa keputusan Allah itu justru yang terbaik baginya. Sikap sabar dan syukur dalam menerima ketentuan Tuhan adalah salah satu perilaku terpuji dan mendapat kedudukan utama dalam menentukan kesempurnaan pribadi. Dalam cerita rakyat ini mengajarkan tentang akhlak kita kepada takdir Allah, dijelaskan sebagai berikut.

(a). Sabar adalah sikap jiwa yang ditampilkan dalam penerimaan terhadap sesuatu, baik berkenaan dengan penerimaan tugas dalam bentuk suruhan dan larangan maupun bentuk penerimaan terhadap perlakuan orang lain, serta sikap menghadapi suatu musibah.

(b). Syukur adalah sikap dan perilaku yang menunjukkan penerimaan terhadap suatu pemberian atau anugerah dalam bentuk pemanfaatan dan penggunaan yang sesuai dengan kehendak pemberinya. Syukur kepada Tuhan adalah berterima kasih dalam bentuk ucapan dan perbuatan yang diinginakn oleh Tuhan sang Maha Pemberi.
Analisis pragmatis yang dilakukan pada cerita rakyat tersebut terdapat nilai-nilai pendidikan yang meliputi nilai moral, nilai sosial, dan nilai religius.

(a). Nilai moral diwujudkan dengan perbuatan menyayangi dan bertanggung jawab terhadap orang tua, saling menasihati dalam keluarga, menaati nasihat orang tua, menepati janji.

(b). Nilai sosial diwujudkan dengan perbuatan peduli sesama, tidak melakukan kekerasan, ikhlas, dan memaafkan kesalahan orang lain.

(c). Nilai Religius terbagi menjadi dua yaitu aqidah ditunjukkan dengan tauhid, kepercayaan terhadap alam gaib, dan iman kepada takdir sedangkan akhlak ditunjukkan dengan akhlak kepada Allah yaitu beribadah, berdoa kepada Allah, dan tawakkal kepada Allah selanjutnya Akhlak kepada orang tua ditunjukkan dengan menyayangi dan mencintai orang tua, menaati perintah orang tua, meringankan beban orang tua, dan menyantuni orang tua.

\section{Daftar Pustaka}

Alaini, Nining Nur. 2005. Proyek Penelitian Mandiri:Jenis-jenis Karya Sastra di Kabupaten Sumbawa Barat. Mataram: Pusat Bahasa Departemen Pendidikan dan Kebudayaan.

Hindrayanti. 2009. Aspek Religiusitas dalam Novel Hafalan Shalat Delisa Karya tere Liye. Skripsi. FKIP: Universitas Mataram.

Kosasih, E. 2009. Bank Soal Bahasa Indonesia. Bandung:CV.Yrama Widya.

Nurgiyantoro, Burhan. 2010. Sastra Anak. Yogyakarta: Gadjah Mada University Pres.

Nurgiyantoro, Burhan. 2010. Teori Pengkajian Fiksi. Yogyakarta: Gadjah Mada University Pres.

Semi, Atar. Tanpa tahun. Kritik Sastra. Bandung: Penerbit Angkasa.

Stanton, Robert. 2007. Teori Fiksi Robert Stanton. Yogyakarta: Pustaka Belajar.

\section{Penutup}


Sugiyono. 2011. Metode Penelitian Kuantitatif, Kualitatif, dan R\&D. Bandung: CV. Alfabeta

Tim Penyusun Kamus Pusat Bahasa. 2007. Kamus Besar Bahasa Indonesia. Edisi Ketiga. Jakarta: Balai Pustaka.
Wahyuningtyas, Sri dan Wijaya Heru Susanto. 2011. Sastra: Teori dan Implementasi. Surakarta: Yuma Pustaka.

Wiyatmi. 2008. Pengantar Kajian Sastra. Yogyakarta: Pustaka. 